\title{
UPORABNOST KARTIRANJA VINOGRADOV KOT METODE ZA UGOTAVLJANJE PROSTORSKIH ZNAČILNOSTI TERMALNEGA PASU
}

\author{
Darko Ogrin \\ Oddelek za geografijo, Filozofska fakulteta, Univerza v Ljubljani \\ Aškerčeva 2, SI-I000 Ljubljana, Slovenija \\ e-mail: darko.ogrin@ff.uni-lj.si
}

Izvirni znanstveni članek

COBISS 1.01

\section{Izvleček}

Na primeru treh Obpanonskih pokrajin v vzhodni Sloveniji je prikazana metoda določanja prostorskih značilnosti termalnega pasu s pomočjo natančnega kartiranja vinogradov. Rezultati so potrdili primernost metode, obenem pa kažejo na nekatere njene omejitve. Uporabna je predvsem v pokrajinah z zelo dolgo tradicijo vinogradništva in pri prebivalstvu izoblikovanim poznavanjem lokalnih klimatskih razmer. Dobre rezultate daje v reliefno razčlenjenih pokrajinah. Rezultati odražajo prostorske značilnosti termalnega pasu v začetku rasti vinske trte spomladi, ko je ta najbolj občutljiva za pozebe.

Ključne besede: topoklima, lokalna klima, vertikalna klimatska pasovitost, termalni pas, kartiranje vinogradov, behaviorizem, Obpanonske pokrajine.

\section{APPLICABILITY OF VINEYARD MAPPING AS THE METHOD OF DETERMINING SPATIAL CHARACTERISTICS OF THERMAL BELT}

\begin{abstract}
In three peri-Pannonian regions in east Slovenia was tested method of determining spatial features of thermal belt by means of a detailed mapping of vineyards. The results corroborated the applicability of the method, however also exposed some of the method's limitations. It is suitable primarily for the areas with a lasting winegrowing tradition and with the population well informed about the local climate conditions. It yields good results in landscapes having strongly dissected landforms. The obtained results reflect spatial characteristics of thermal belt particularly at the beginning of the growth in spring when vine is most sensitive to frosts.
\end{abstract}

Key words: topoclimate, local climate, vertical climate zoning, thermal belt, vineyard mapping, behaviourism, peri-Pannonian regions. 


\section{UVOD}

V slovenski geografiji se je $\mathrm{z}$ vertikalno klimatsko pasovitostjo in $\mathrm{v}$ okviru nje $\mathrm{z}$ definicijo in obsegom termalnega pasu prvi ukvarjal Gams (1972). Pojmuje ga kot pas, ki leži nad dnom kotlin, dolin in kraških depresij, kjer se ob anticiklonalnem tipu vremena pojavi temperaturna inverzija z jezeri hladnega zraka, in je zaradi tega toplejši od inverznega pasu. Prav tako je toplejši tudi od višje ležečih predelov nad njim, kjer temperatura zraka pada zaradi višje nadmorske višine. V termalnem pasu so višje zlasti minimalne temperature (absolutne in povprečne), kar je v kmetijstvu zelo pomembno za gojenje toplotno zahtevnejših kultur. Zaradi manjše nevarnosti pozeb so npr. v termalnem pasu prisoj gričevja slovenskih Obpanonskih pokrajin praktično vsi vinogradi in večina sadovnjakov, v Obsredozemskih pokrajinah pa oljčniki.

Gams (1996) je s primerjavo temperaturnih podatkov meteoroloških postaj v dnu dolin (kotlin) in bližjih na pobočjih v termalnem pasu ugotovil, da imajo postaje v termalnem pasu v Sloveniji za približno $2{ }^{\circ} \mathrm{C}$ višje povprečne minimalne temperature. Primerjava za Pomurje pa je pokazala, da so kraji v dnu dolin samo tri mesece na leto brez slane, kraji dobrih $150 \mathrm{~m}$ nad dolinami pa so brez slane kar šest mesecev.

Poseben problem je natančnejša določitev spodnje in zgornje meje termalnega pasu. S klimatološkega vidika je to pomembno npr. pri določanju topoklimatskih enot in topoklimatskem kartiranju (Vysoudil, 1993), z aplikativnega pa pri načrtovanju kulturne izrabe pokrajine, npr. v kmetijstvu in pri poselitvi. Določanje obsega termalnega pasu s pomočjo dolgoletnih povprečij klimatskih meritev je v posameznih slovenskih pokrajinah praktično nemogoče, ker je pokritost ozemlja $\mathrm{z}$ meteorološkimi postajami preredka. S pomočjo teh podatkov lahko določimo le orientacijsko zgornjo mejo na nivoju celotne Slovenije. Povprečne minimalne temperature jo nakazujejo pri okoli 500 m relativne višine, povprečne letne temperature pa pri 200 do 250 m nad dnom dolin (Gams, 1996; Žiberna, 1999; Ogrin, 2000).

Kot alternativna metoda za določanje obsega termalnega pasu se pri topoklimatskih členitvah in topoklimatskem kartiranju ponujajo profilne meritve minimalnih temperatur ob posameznih vremenskih situacijah in podrobno kartiranje rastišč toplotno zahtevnih kultur, npr. vinske trte in oljke. Primerjava rezultatov profilnih meritev minimalnih temperatur ob anticiklonalnem vremenu s prostorsko razporeditvijo vinogradov in oljčnikov na testnih območjih je namreč pokazala dobro sovpadanje obsega termalnega pasu, dobljenega $\mathrm{s}$ pomočjo obeh metod. Vinogradi nakazujejo spodnjo mejo termalnega pasu med 15 in $30 \mathrm{~m}$ nad dnom dolin in zgornjo pri približno 450 do $550 \mathrm{~m}$ n.v. (Žiberna, 1992), oljke pa od 10 do $40 \mathrm{~m}$ nad dolinami do okoli 250, redkeje $300 \mathrm{~m}$ n.v. (Ogrin in Mužina, 2005).

Glede na predhodne rezultate in priporočila v strokovni literaturi (npr. Geiger, 1966), da lahko ob pomanjkanju podatkov meteoroloških postaj dobimo vpogled $\mathrm{v}$ osnovno klimatsko zgradbo neke pokrajine tudi z analizo modifikatorjev, ki vplivajo na klimatske značilnosti, in posebnostmi $v$ naravni vegetaciji in kulturni izrabi pokrajine, smo poskušali določiti obseg in značilnosti termalnega pasu v slovenskih Obpanonskih pokrajinah s pomočjo kartiranja vinogradniških površin. Tradicija vinogradništva v teh pokrajinah sega $\mathrm{v}$ čas rimskega imperija, zato smo predpostavili, da se je skozi tisočletno tradicijo pri ljudeh 
dodobra izoblikovalo znanje o za trto optimalnih legah, kjer je nevarnost pozeb najmanjša in so klimatski pogoji za rast in dozorevanje grozdja najboljši.

Pri terenskem delu za potrebe raziskave je sodelovalo več generacij študentov drugega letnika geografije, ki so v okviru terenskih vaj iz fizične geografije v študijskih letih 2000/01 do 2003/04 raziskovali najprej v Beli krajini, nato v študijskem letu 2004/05 na Goričkem. Vsem se za vloženi trud na tem mestu iskreno zahvaljujemo. Zahvala gre tudi študentom, ki so problematiko termalnega pasu in z njim povezane probleme obdelovali za potrebe seminarskih nalog v okviru seminarja iz Klimatogeografije ali Fizične geografije Slovenije (Lupše, 2001; Marinčič, 2006), na rezultate katerih se v prispevku tudi sklicujemo.

\section{RAZISKOVALNA OBMOČJA IN TEORETIČNO METODOLOŠKA IZHODIŠČA}

Za določitev značilnosti termalnega pasu s pomočjo kartiranja vinogradov v gričevju Obpanonskih pokrajin smo izbrali tri raziskovalna območja: Goričko na severu, Posotelje $\mathrm{v}$ osrednjem delu in Belo krajino na jugu (Slika 1). Kartiranje je potekalo neposredno na terenu, vinogradniške površine smo vnašali v topografsko karto merila 1:5000. Posebej smo bili pozorni na zgornjo in spodnjo mejo vinogradov ter na višino spodnje meje nad dnom dolin. Zaradi prepričanja o dobrem poznavanju lokalnih podnebnih razmer pri ljudeh in upoštevanja tega znanja $\mathrm{v}$ praksi smo postavili tezo, da omejujeta spodnja in zgornja višinska meja vinogradov termalni pas (območje manjše ogroženosti zaradi pozeb), spodnja meja pa je hkrati tudi povprečna višina jezer hladnega zraka $v$ topli polovici leta oziroma $\mathrm{v}$ začetku rasti vinske trte, ko je ta za pozebo najbolj občutljiva. Terensko delo smo izkoristili tudi za intervjuje z domačini. Povpraševali smo jih o lokalnih vremenskih in klimatskih značilnostih, predvsem o ogroženosti zaradi slan in pozeb. Posebej so nas zanimali tudi kriteriji, ki jih uporabljajo za lociranje novih vinogradov.

Pri interpretaciji rezultatov dobljenih s kartiranjem in intervjuji smo se zavedali dejstva, da je za ravnanje ljudi pogosto bolj pomembna njihova zaznava pokrajine in njenih značilnosti (tudi podnebnih), kot pa stvarne razmere in da so nam ljudje poleg informacij, ki dejansko obstajajo v pokrajini, med miselno preslikavo informacij iz pokrajine dodali tudi njihov lastni odnos do njih. V bistvu smo se s tem delom raziskave dotaknili vedenjske ali behavioristične geografije, ki se je v geografiji in drugih znanostih pojavila v 60. letih 20. stoletja kot nasprotje tedaj povsem prevladujočemu pozitivizmu (Kaplan et al., 2004). Behavioristična geografija meni, da človek ni stroj, ki bo na dražljaje iz zunanjega sveta reagiral vedno na enak način, ampak so njegove reakcije, ki skozi dejanja preoblikujejo pokrajino, rezultat odnosa med posameznikom in njegovim okoljem. Delovanje človeka je zatorej izključno rezultat reakcije na miselno podobo, ki si jo je ustvaril v svoji glavi, ne pa na dejansko podobo, saj za posameznika obstaja le ena pokrajina, to je dojeta (Johnston et al., 2003). Iz tega izhaja, da se ljudje v okviru lastnega znanja in razumevanja pokrajinskih razmer obnašajo racionalno, vendar dojeto okolje ni enako dejanskemu oziroma tistemu, ki ga dojema raziskovalec. Ljudje sprejemajo različne odločitve v zvezi s svojim okoljem, vendar so odločitve pogosto naučene in izhajajo iz navad in večkratnih ponavljajočih se odločitev. To v konkretnem primeru 
pomeni, da je termalni pas, ugotovljen s pomočjo kartiranja vinogradov, večinoma rezultat tradicije in številnih poskusov iskanja optimalnih leg za trto več generacij. Kot tak absolutno ne sovpada s termalnim pasom, ki bi ga $\mathrm{v}$ konkretni pokrajini dobili s pomočjo empiričnih raziskav in se lahko njegove prostorske značilnosti od kraja do kraja spreminjajo, pa ne nujno kot posledica razmer v pokrajini, ampak zaradi razlik v dojemanju pokrajinske stvarnosti (tudi podnebja) pri ljudeh.

Slika 1: Geografski položaj raziskovalnih območij.

Figure 1: Geographical position of investigated areas.

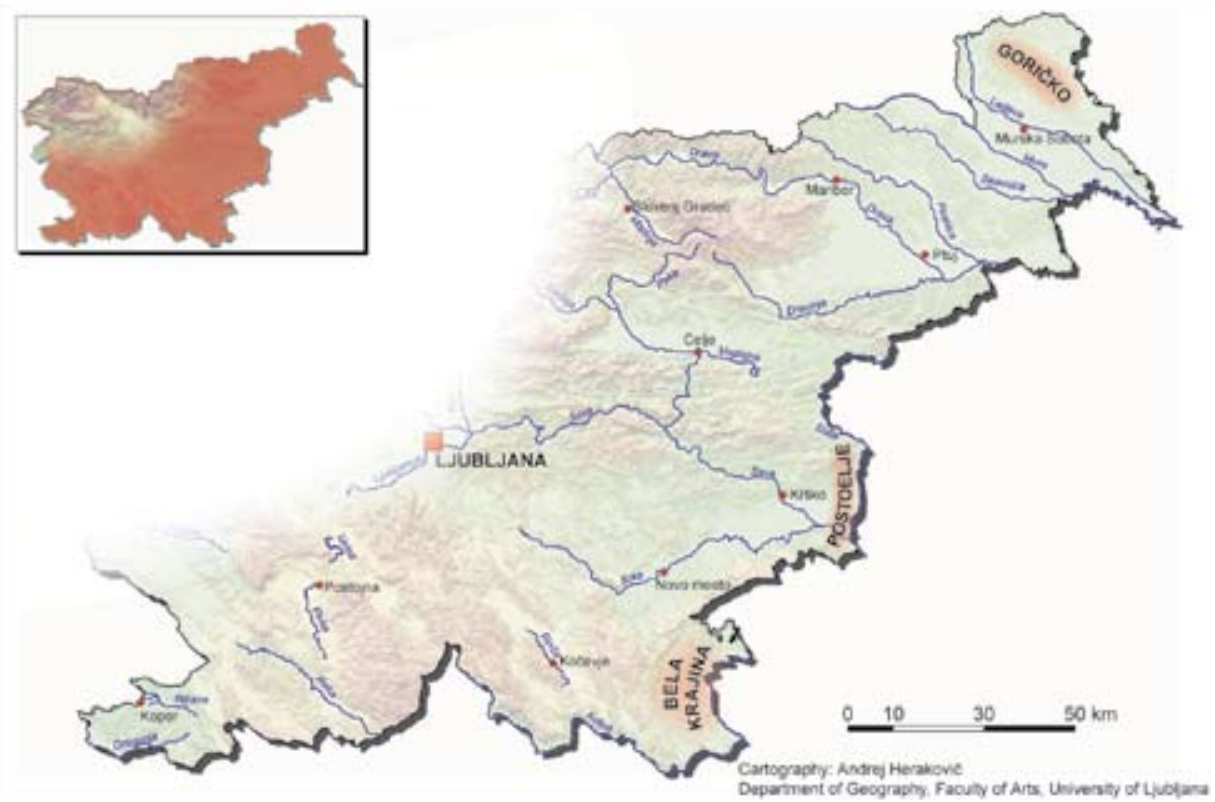

Za lažje ovrednotenje s kartiranjem dobljenih rezultatov smo na izbranih raziskovalnih območjih opravili tudi več profilnih meritev minimalnih temperatur ob anticiklonalnem vremenu. Z njimi smo dobili vpogled $v$ obseg, intenzivnost in prostorske značilnosti inverzije in inverznega pasu ter termalnega pasu nad njim ob posameznih vremenskih situacijah. Večji poudarek smo dali meritvam $v$ topli polovici leta, ko so inverzija in v povezavi z njo minimalne temperature ter spomladanske pozebe pomembne za kulturne rastline. Na izbranih profilih, ki so potekali od dna dolin (ravnin) do vrha gričevij, smo z digitalnim termometrom, ki je bil pritrjen na avtomobil, ob stalni hitrosti okoli $40 \mathrm{~km} / \mathrm{h}$ merili temperaturo na 20 do 40 reprezentativnih mestih, odvisno od dolžine profila. Meritve so potekale tik pred sončnim vzhodom, ko so temperature najnižje. 


\section{TERMALNI PAS KAKOR GA NAKAZUJEJO VINOGRADI}

\section{I Termalni pas v Beli krajini}

V Beli krajini smo vinogradniške površine kartirali na 34 lokacijah. Posebej smo obdelali razpršene vinograde na holmih na ravniku in v dolini Kolpe, ter vinograde na dvignjenem obodu od Poljanske gore do Gorjancev, ki se pojavljajo v bolj ali manj strnjenem pasu. Vinogradi na holmih se večinoma začnejo okoli $10 \mathrm{~m}$ nad nivojem ravnika, v neredkih primerih segajo tudi do njega. Problem pri določitvi spodnje meje je bilo zelo razgibano površje s številnimi vrtačami in drugimi bolj ali manj izrazitimi kotanjami. V dolini Kolpe je spodnja meja vinogradov višje nad dnom doline, od 25 do $80 \mathrm{~m}$. To je verjetno posledica manjše osončenosti pri dnu zaradi višjega horizonta in večje vlažnosti zraka, ki trti zaradi večje nevarnosti bolezni ne ustreza. Zgornja višinska meja, do koder segajo vinogradi, je med 260 in $360 \mathrm{~m}$ in je večinoma pogojena $\mathrm{z}$ višino holmov in pobočij nad Kolpo. Več kot polovica kartiranih vinogradov (58 \%) ima južno ekspozicijo, sledita JZ (34\%) in JV (8\%).

Vinogradi na hribovitem obodu Bele krajine imajo bolj izrazito spodnjo in zgornjo mejo. Večina se jih začne 10 do $40 \mathrm{~m}$ nad nivojem ravnika (190 do $250 \mathrm{~m}$ n.v.) in segajo po pobočjih navzgor do največ $200 \mathrm{~m}$ relativne višine (do n.v. okoli $425 \mathrm{~m}$ ). Vinogradniški pas ima vertikalni obseg od $50 \mathrm{~m}$ pri Drašičih, pa do $200 \mathrm{~m}$ pri Semiču. Zaradi usmerjenosti pobočij oboda Bele krajine imajo vinogradi nekoliko drugačno razporeditev ekspozicij kot tisti na ravniku. Največ jih ima JV lego (45\%), sledijo južna (28\%), JZ (14\%) in vzhodna $(9 \%)$.

Termalni pas, kakor ga nakazujejo vinogradi, dobro sovpada z ugotovitvami, ki so jih nakazale meritve minimalnih temperatur ob anticiklonalnem vremenu $\mathrm{v}$ topli polovici leta. V obdobju 2001-2004 smo opravili 9 merilnih kampanj na različnih profilih. V nadaljevanju predstavljamo rezultate dveh najbolj reprezentativnih. Prve, ki je potekala od doline Kolpe do vrha vinogradniškega holma sredi ravnika in druge, ki je potekala čez ravnik do hribovitega oboda. Za prvo kampanjo (6.5.2002; 5:39 do 6:03) od doline Kolpe pri Pobrežju (150 m n.v.) do vrha Velike Plešivice (363 m n.v.) je bila značilna plitva inverzija. Najnižje temperature, med 7,3 in $8{ }^{\circ} \mathrm{C}$, smo namerili po blagih depresijah (vrtačah) na ravniku. Ob Kolpi so bile temperature nekoliko višje, 8 do $8,5^{\circ} \mathrm{C}$, medtem ko so bile na Plešivici med 10 in $12,5^{\circ} \mathrm{C}$, torej 2 do 5 stopinj višje kot na ravniku. Na plitva jezera hladnega zraka debeline 5 do $10 \mathrm{~m}$ je opozarjala tudi megla $\mathrm{v}$ dolini Kolpe in po depresijah na ravniku.

Podobne značilnosti je imela tudi inverzija 12.5.2002, ko smo med 5:18 in 5:57 merili temperaturo od Marindola ( $220 \mathrm{~m}$ n.v.) do Vrčic nad Semičem (480 m n.v.). Na ravniku so bile temperature med 9 in $12{ }^{\circ} \mathrm{C}$, najvišje so bile na obodu v nadmorski višini med 230 in $400 \mathrm{~m}$ (med 12 in $16^{\circ} \mathrm{C}$ ), nato so se $\mathrm{z}$ naraščajočo nadmorsko višino zniževale. Te meritve nakazujejo termalni pas med 230 in $400 \mathrm{~m}$ n.v.. Pod termalnim pasom je bilo jezero hladnega zraka (inverzijsko območje) debeline 10 do $30 \mathrm{~m}$, nad njim pa hribski pas, ki je zelo lepo razviden tudi iz meritev 19.8.2003 (Slika 3). 
Slika 2: Termalni pas $v$ Beli krajini (JV Slovenija) kakor ga nakazujejo vinogradi.

Figure 2: Thermal belt in Bela Krajina (SE Slovenia) as indicated by the vineyards.

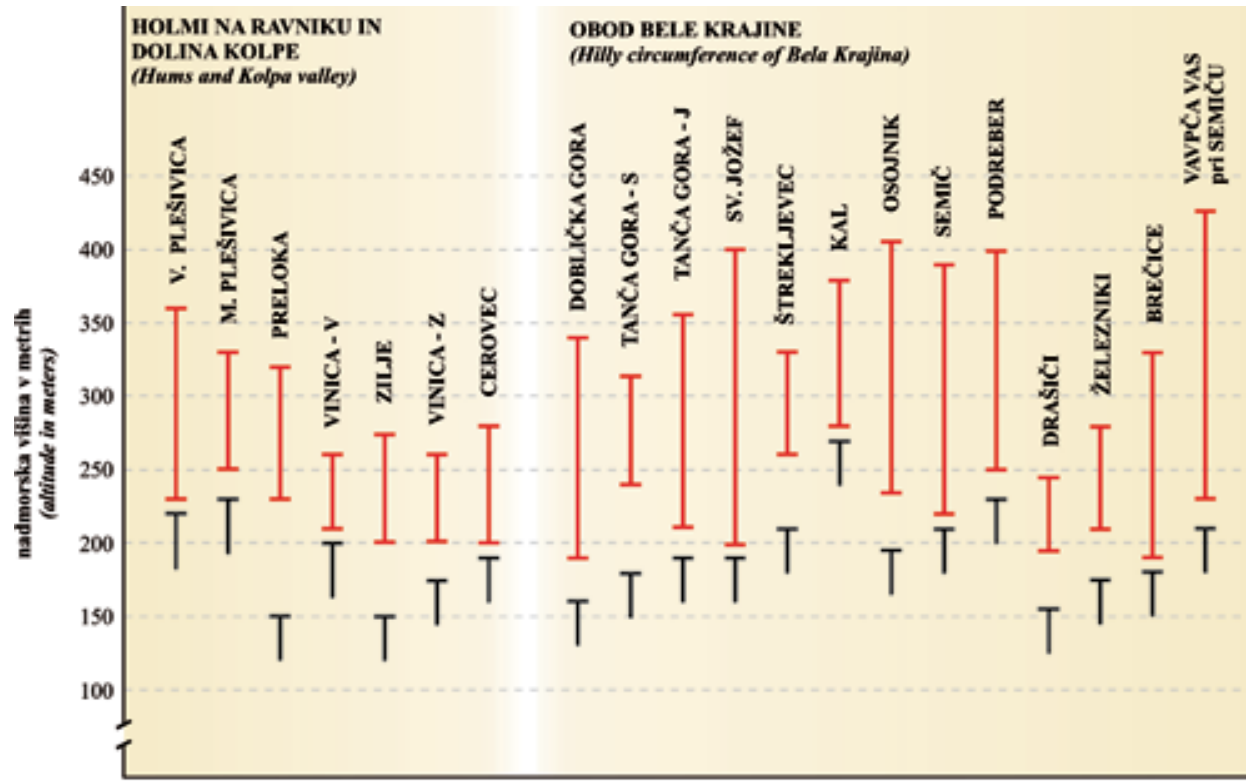

I termalni pas $\begin{aligned} & \text { thermal belt) } \\ & \text { (the }\end{aligned}$ (the bottom of the valley, plane)

S pomočjo predstavljenih in ostalih meritev v Beli krajini lahko sklepamo, da so za toplo polovico leta, ko so noči kratke in pogoji za ohlajevanje zraka slabši, značilne plitve inverzije, ki se razkrojijo kmalu po sončnem vzhodu. V dolini Kolpe in v depresijah na ravniku so temperature od 4 do 6,5 stopinj nižje kot $\mathrm{v}$ termalnem pasu. Ta ima v topli polovici leta večji vertikalni obseg, začne se od 5 do $10 \mathrm{~m}$ nad nivojem ravnika in sega do okoli 350 $\mathrm{m}$ relativne višine. Najtoplejši pa ni termalni pas na hribovitem obodu Bele krajine, saj so nad njim pobočja višjega hribskega pasu, po katerih polzi hladen zrak v nižje predele. Kot najtoplejši so se izkazali višji osamljeni holmi na ravniku, ki v topli polovici leta segajo nad inverzijsko plast hladnejšega zraka. Zato ne preseneča da so, tako kot termalni pas na obodu, tudi nekateri holmi izrazito vinogradniški in da na nekaterih vrtovih rastejo tudi fige (npr. v Preloki). Po izjavah domačinov fige v celoti nikoli ne pozebejo, prva generacija fig v juliju redno dozori, druga $v$ začetku jeseni pa velikokrat ne, ker jo prehiti mraz.

Glede na predstavljene meritve naj bi termalni pas v Beli krajini v topli polovici leta segal do 350 m relativne višine, vinogradi pa ga nakazujejo nižje, do največ 200 m relativne višine oziroma do 425 m n.v. Da vinogradi ne gredo višje, je marsikje posledica tudi prestrmega reliefa. Ko smo domačine spraševali, kaj so glavni kriteriji za lociranje novega vinograda, jih je velika večina omenjala tradicijo in ustno izročilo (»Naši ta stari so dobro vedeli, kje je najmanjša nevarnost pozeb in kje so vinogradi najbolj obrnjeni proti soncu«) oziroma stare 
vinograde, ki so bili na izbrani lokaciji že v preteklosti. Točnih odgovorov na vprašanje, kako nizko v dolino lahko sega vinograd, nismo dobili. Odgovarjali so, da preveč v dno ni smiselno saditi, ker trta rada pozebe. Še najbolj natančen je bil odgovor starejšega domačina iz Preloke, ki je razložil, da so trto pod vasjo proti Kolpi sadili »do horizonta«. Torej do višine kraškega ravnika na hrvaškem bregu reke, to je do okoli 40 m nad dnom doline.

Slika 3: Minimalne temperature ob anticiklonalnem vremenu v Beli krajini na profilu od Črnomlja (160 m n.v.) do Planine pod Mirno goro (720 m n.v.) (19.8.2003; 4:30-5:05) (A) in vinogradniški pas pri Semiču (B); foto: D. Ogrin).

Figure 3: Minimum temperatures during anticyclonic weather conditions in Bela Krajina along the profile from Crnomelj (160 $\mathrm{m}$ above sea level) to Planina pod Mirno goro (720 $\mathrm{m}$ a.s.l.) (19 August 2003; 04:30-05:05) (A) and the vineyard belt near Semič (B); (photo: D. Ogrin)
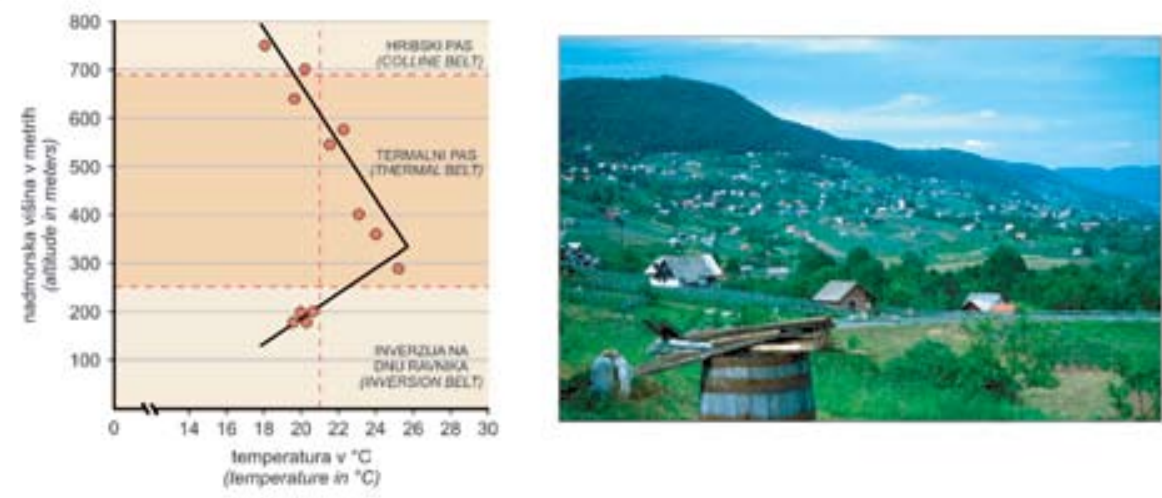

\subsection{Termalni pas v Posotelju}

V Posotelju smo vinograde kartirali na 6 lokacijah v okolici Imenega in Virštajna. Gre za izrazito vinogradniško pokrajino z vinogradi na prisojni strani gričevja. Vinogradi se začnejo okoli $40 \mathrm{~m}$ nad dnom doline Sotle oziroma Golobinjskega potoka in gredo do najvišjih vrhov gričevja, to je nad $400 \mathrm{~m}$ n.v. (Preglednica 1). S pomočjo vinogradov lahko v Posotelju ugotavljamo samo spodnjo mejo termalnega pasu, ki se začne večinoma 30 do 40 $\mathrm{m}$ nad dnom dolin. Zaradi nizkega reliefa pa ne moremo ugotavljati njegove zgornje meje in vertikalnega obsega termalnega pasu, ker bi vinsko trto sadili še višje, če bi višinske razmere to dopuščale. To nam dokazujejo primeri iz ostalih, višjih gričevij Obpanonskih pokrajin, kjer uspeva vinska trta tudi nad 500 m n.v.

Vinogradi v Srednjem Posotelju kažejo na povprečno debelino inverzne plasti zraka med 30 in 40 m. Ugotovitev smo skušali, podobno kot v primeru Bele krajine, preveriti tudi s profilnimi meritvami minimalnih temperatur ob anticiklonalnem vremenu (Lupše, 2001). Marca 2000 smo opravili tri merilne kampanje. Vsakič smo v okolici Virštajna, Imena in Podčetrtka opravili meritve na 58 točkah od dna dolin po pobočjih do vrha gričevja. Izbirali smo termine, ko smo pričakovali slano. 
Preglednica 1: Hipsometrične značilnosti vinogradov v Srednjem Posotelju.

Table 1: Hypsometric features of vineyards in Srednje (Middle) Posotelje.

\begin{tabular}{|l|c|c|c|c|c|}
\hline $\begin{array}{l}\text { Lokacije } \\
\text { kartiranja } \\
\text { (Mapping } \\
\text { location) }\end{array}$ & $\begin{array}{c}\text { Zgornja meja } \\
\text { vinogradov } \\
\text { (Upper limit } \\
\text { of vineyards) }\end{array}$ & $\begin{array}{c}\text { Spodnja } \\
\text { meja } \\
\text { vinogradov } \\
\text { (Lower limit } \\
\text { of vineyards) }\end{array}$ & $\begin{array}{c}\text { Vertikalni } \\
\text { obseg } \\
\text { vinogradov } \\
\text { (Vertical } \\
\text { extend of } \\
\text { vineyards) }\end{array}$ & $\begin{array}{c}\text { Nadmorska } \\
\text { višina dna } \\
\text { doline } \\
\text { (Altitude } \\
\text { above sea } \\
\text { level of } \\
\text { the valley } \\
\text { bottom) }\end{array}$ & $\begin{array}{c}\text { Relativna višina } \\
\text { spodnje meje } \\
\text { vinogradov nad } \\
\text { dnom doline } \\
\text { (Relative height } \\
\text { of the lower limit } \\
\text { of vineyards above } \\
\text { the valley bottom) }\end{array}$ \\
\hline Virštajn & $438 \mathrm{~m}$ & $250 \mathrm{~m}$ & $188 \mathrm{~m}$ & $215 \mathrm{~m}$ & $35 \mathrm{~m}$ \\
\hline Plohov breg & $376 \mathrm{~m}$ & $260 \mathrm{~m}$ & $116 \mathrm{~m}$ & $210 \mathrm{~m}$ & $50 \mathrm{~m}$ \\
\hline Kristan vrh & $381 \mathrm{~m}$ & $240 \mathrm{~m}$ & $141 \mathrm{~m}$ & $200 \mathrm{~m}$ & $40 \mathrm{~m}$ \\
\hline Imenska gorca & $355 \mathrm{~m}$ & $250 \mathrm{~m}$ & $105 \mathrm{~m}$ & $210 \mathrm{~m}$ & $35 \mathrm{~m}$ \\
\hline Imeno & $258 \mathrm{~m}$ & $230 \mathrm{~m}$ & $28 \mathrm{~m}$ & $195 \mathrm{~m}$ & $25 \mathrm{~m}$ \\
\hline Sela & $272 \mathrm{~m}$ & $230 \mathrm{~m}$ & $42 \mathrm{~m}$ & $195 \mathrm{~m}$ & $37 \mathrm{~m}$ \\
\hline $\begin{array}{l}\text { Povprečje } \\
\text { (Average) }\end{array}$ & $280 \mathrm{~m}$ & $240 \mathrm{~m}$ & $103 \mathrm{~m}$ & $204 \mathrm{~m}$ & $40 \mathrm{~m}$ \\
\hline
\end{tabular}

Vir: Lupše, 2001

Rezultati vseh treh merilnih kampanj so si podobni. Najnižje temperature, od -3 do $-5,5{ }^{\circ} \mathrm{C}$, smo namerili v samem dnu dolin. Na prehodu dolin v gričevje in v spodnjem delu gričevja so bile temperature med 0 in $-3{ }^{\circ} \mathrm{C}$, do tu je bila tudi slana. V zgornjem delu gričevja in na temenu gričevja pa med 0 in $5,5^{\circ} \mathrm{C}$. Razlika med najhladnejšimi in najtoplejšimi predeli je bila ob meritvah 7.3.2000 7,3 ${ }^{\circ} \mathrm{C}, 8.3 .200010,4{ }^{\circ} \mathrm{C}$ in 13.3.2000 6,7 ${ }^{\circ} \mathrm{C}$. Meritve kažejo na tipične inverzne razmere, $\mathrm{z}$ naraščanjem temperature $\mathrm{z}$ nadmorsko višino. Vertikalni temperaturni gradient je bil zelo velik ( +7 do $\left.8^{0} / 100 \mathrm{~m}\right)$, saj je višinska razlika med dolinami in temeni gričevja le 150 do $200 \mathrm{~m}$. Če vzamemo izotermo $0{ }^{\circ} \mathrm{C}$ kot zgornjo mejo inverznega in spodnjo mejo termalnega pasu, lahko sklepamo, da se je ob naših meritvah termalni pas začel 50 do 70 m nad dnom dolin, to je višje, kakor ga nakazujejo vinogradi. Rezultat kljub temu ni presenetljiv, saj so meritve potekale v marcu, ko so zaradi dobrih pogojev za nočno ohlajanje zraka jezera hladnega zraka praviloma globlja.

Prebivalstvo v Posotelju in na Kozjanskem se dobro zaveda lokalnih klimatskih razlik in večje nevarnosti pozeb po dolinah. Kot orientacijska višina, do katere je ta nevarnost večja, jim služi višina megle. Meglo neposredno povezujejo s pozebami: »V naši vasi se pozebe ne pojavljajo, saj se megla zadržuje v nižje ležečih dolinah. Pozebe se ne bojimo, saj jeziki megle do nas nikoli ne sežejo«. V osnovi je njihova razlaga pravilna, saj je večina pozeb radiacijskih, do katerih pride zaradi radiacijskega ohlajanja površja in prizemnega sloja zrak. Isti proces povzroči tudi nastanek megle, le če je zrak dovolj vlažen in se ohladi pod temperaturo rosišča. Eden od informatorjev je tudi razložil, zakaj pri njih ne sadijo vinogradov do dna doline: »Včasih se megla vzpne tudi po dnu dolinice pod Vinico, zato so prve vrste vinogradov nekaj $10 \mathrm{~m}$ nad dnom«. O trajanju nevarnosti spomladanskih pozeb pa pravijo: »Če do Zofke (15. maj; op. avtorja) ni bilo pozebe, je tudi ne bo« (Marinčič, 2006). 


\subsection{Termalni pas na Goričkem}

$\mathrm{Na}$ Goričkem, kjer smo vinograde kartirali na 34 lokacijah v vzhodnem delu gričevja, so razmere nekoliko specifične. Vinogradi gredo do najvišjih vrhov gričevja, to je 300 do $350 \mathrm{~m}$ n.v., oziroma jih je zaradi ugodnih reliefnih in klimatskih razmer največ na širokih temenih gričevja, celo več kot na prisojnih pobočjih. Razen lege nad inverzno plastjo zraka je na temenih zelo dolgo tudi sončevo obsevanje, saj je horizont zelo odprt in ni reliefnih ovir, ki bi ga skrajševale. Poudariti velja, da je zaradi blagega reliefa $\mathrm{z}$ majhnimi relativnimi višinskimi razlikami osončenost tudi v dolinah dobra. V zimskem času, ko je Sonce nizko nad horizontom, je v globljih dolinah trajanje obsevanja zaradi višjega horizonta krajše do 3 ure od teoretično možnega, v poletnem času pa največ do ene ure (Slika 4). Spodnja meja vinogradov je na Goričkem višja kot v Beli krajini in v Posotelju, to je od 50 do $150 \mathrm{~m}$ nad dnom dolin. Zaradi nizkih nadmorskih višin gričevja imajo vinogradi relativno majhen višinski obseg, od 25 do največ $100 \mathrm{~m}$.

$\mathrm{Na}$ Goričkem je zaradi nizkih nadmorskih višin in blagega reliefa ugotavljanje termalnega pasu s pomočjo vinogradov vprašljivo. V samem dnu plitvih dolin vinogradov sicer ni, po izjavi enega od informatorjev zato, »ker se s tem izognejo pozebam, ki so letos (spomladi 2005, op. avtorja), po dolinah že pomorile češnje«. Kljub ugodnejšim temperaturnim razmeram niso v večjem številu zastopani niti na pobočjih, ampak so zaradi ugodnejših reliefnih razmer in razmer glede osončenja skoncentrirani na temenih gričevja.

Slika 4: Potek realnega horizonta in trajanje sončevega obsevanja na temenu gričevja (Magašev breg) in v dnu doline (Sukičev potok) na Goričkem (SV Slovenija).

Figure 4: The course of real horizon and the duration of insolation on the ridge of the hills (Magašev breg) and at the bottom of the valley (Sukičev potok) in Goričko region (NE Slovenia).
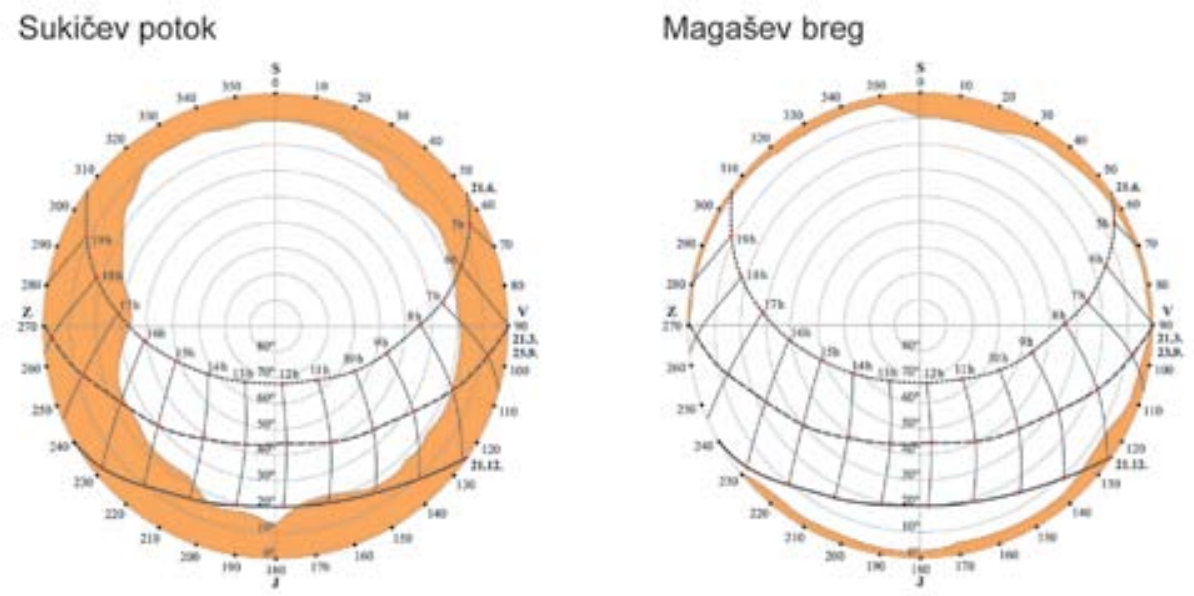


\section{SKLEP}

Splošne značilnosti termalnega pasu so v reliefno razgibani Slovenije dobro poznane. Velikokrat pa pride do težav, ko je potrebno termalni pas definirati in ugotoviti njegove značilnosti na lokalnem nivoju, npr. pri topoklimatskem kartiranju in topoklimatskih členitvah. Ker je običajno mreža uradnih meteoroloških postaj za študije na tem nivoju preredka in ni na razpolago dovolj meritev, so primerne razne posredne metode ugotavljanja klimatskih značilnosti. Mednje spada tudi kartiranje klimatsko zahtevnih rastlin in kultur, kamor sodi tudi vinska trta.

$\mathrm{V}$ prispevku predstavljeni rezultati $\mathrm{v}$ osnovi pritrjujejo prejšnjim ugotovitvam, da lahko s pomočjo razprostranjenosti vinogradov ugotovimo glavne prostorske značilnosti termalnega pasu, kot ene od enot klimatske zgradbe pokrajine. Vendar ima ta metoda svoje posebnosti in omejitve, ki izhajajo tudi iz značilnosti behaviorističnega pristopa. V poštev pride predvsem tam, kjer je tradicija vinogradništva zelo dolga (stoletna, tisočletna) in je faza eksperimentiranja z iskanjem optimalnih leg za to kulturo že mimo. Predpostavlja, da je skozi tradicijo ljudsko podnebjeslovje izoblikovalo znanje o ugodnih legah in mejah, do katerih se je $\mathrm{z}$ vinsko trto še smiselno ukvarjati. Dobre rezultate daje v razgibanem reliefu $\mathrm{z}$ dovolj izrazito višinsko razčlenjenostjo, kjer so višinski klimatski pasovi in posebnosti v kulturni izrabi pokrajine povezane z njimi dovolj izrazite. V našem primeru se je kot najbolj primeren izkazal hriboviti obod Bele krajine. Pri opredelitvi termalnega pasu s pomočjo kartiranja vinogradov je pomembno tudi zavedanje, da na ta način določen termalni pas, in v povezavi z njim tudi ostali višinski klimatski pasovi, predstavlja predvsem podnebne razmere $v$ začetku rasti vinske trte, to je konec aprila in v maju, ko je ogroženost trte za pozebo največja. Na to dejstvo opozarjajo tudi izjave domačinov in meritve minimalnih temperatur, po katerih je v poletnem času vertikalni obseg termalnega pasu pogosto večji, kot ga nakazujejo vinogradi, pozimi pa zaradi izrazitih inverzij z globokimi jezeri hladnega zraka manjši. Zavedati se je potrebno tudi dejstva, da je termalni pas dinamičen pojav, ki se zelo spreminja tudi v odvisnosti od posameznih vremenskih razmer, na kar kažejo tudi meritve.

\section{Viri in literatura}

Gams, I., 1972. Prispevek k klimatogeografski delitvi Slovenije. Geografski obzornik 191, Ljubljana, str. 1-9.

Gams, I., 1996. Termalni pas v Sloveniji. Geografski vestnik 68, Ljubljana, str. 5-38.

Geiger, R., 1966. The climate near the ground. Cambridge.

Johnston, R., Gregory, D., Pratt G., Watts M., 2003. The Dictionary of Human Geography. Blackwell, Oxford.

Kaplan, D.H., Wheeler J.O., Holloway, S.R., 2004. Urban Geography. Arnold, London.

Lupše, I., 2001. Klimatske značilnosti Srednjega Posotelja s poudarkom na minimalnih temperaturah ob anticiklonalnem vremenu. Seminarska naloga, Oddelek za geografijo FF UL, Ljubljana. 
Marinčič, A., 2006. Poznavanje podnebnih razmer in lokalnih vremenskih posebnosti pri prebivalcih Kozjanskega (primer Ravenskega Loga, Kalobja, Podlešja in Šentvida). Seminarska naloga, Oddelek za geografijo FF UL, Ljubljana.

Ogrin, D., 2000. Nekatere topoklimatske značilnosti razporejanja temperature zraka in burje v razgibanem reliefu Slovenije. Dela 15, Oddelek za geografijo FF UL, Ljubljana, str. $125-138$.

Ogrin, D., Mužina, D., 2005. Pokrajinskoekološke značilnosti območja med Kavčičem in Tinjanom. V: Meje in konfini (ur.: V. Rožac Darovec), Koper, str. 289-332.

Vysoudil, M., 1993. Topoclimatic Mapping in Central Moravia. Geografski vestnik 65, Ljubljana, str. 25-31.

Žiberna, I., 1992. Vpliv klime na lego in razširjenost vinogradov na primeru srednjih Slovenskih goric. Geografski zbornik 32, Ljubljana, str. 50-139.

Žiberna, I., 1999. Temperaturni obrat v hriboviti Sloveniji. Dela 13, Oddelek za geografijo FF UL, Ljubljana, str. 237-248.

\section{APPLICABILITY OF VINEYARD MAPPING AS THE METHOD OF DETERMINING SPATIAL CHARACTERISTICS OF THERMAL BELT}

\section{Summary}

The paper is a continuation of studies about the problems of thermal belt that is, in view of climate features, among the most favourable zones in Slovenia. General characteristics of thermal belt are well known in the agitated landforms of Slovenia. However, troubles often occur when thermal belt is to be determined and its characteristics defined on a local level, as, for example, in topoclimatic mapping and topoclimatic divisions. Since the regular network of national meteorological posts is usually not dense enough for the studies on this level, and the available measurements are insufficient, various indirect methods are suitable for determining climatic features. One of such methods is also the mapping of climatically sensitive plants and cultures among which grapevine also ranks. The method was applied and the testing of results by means of field measurements of the profile was done in three investigation areas in east Slovenia (Bela Krajina, Posotelje, Goričko) havinga millenniumlong winegrowing tradition.

The results in fact corroborate the earlier findings, namely that by means of the range of vineyards it is possible to establish the main spatial characteristics of the thermal belt as one of the constituents of climatic structure of the area. However, this method has its special traits and limitations proceeding also from the characteristics of behaviouristic approach. It is applicable mainly in those areas where the winegrowing tradition is very long (for centuries, a millennium) and the phase of experimenting with the search for optimum positions for this culture has already been over. It functions on the presumption that, in thecourse of tradition, folk climatology has already acquired the necessary knowledge about favourable positions and limits up to which the planting of grapevine still seems reasonable. It yields good results in the agitated landforms with well-defined vertical division, where the vertical climate 
zones and the specific features in the cultural use of landscape related to them are sufficiently explicit. The most suitable in our case has proved to be the hilly rim of Bela Krajina. While determining the thermal belt by means of vineyard mapping, it is important to bear in mind that the thermal belt determined in such a way, and in relation to it also other vertical climate zones, mainly represents climatic conditions at the beginning of growth, that is at the end of April and in May, when grapevine is most sensitive to frost. This fact is also exposed by the statements of local people and the measurements of minimum temperatures that often show greater vertical extent of the thermal belt in summertime than indicated by vineyards, while in wintertime, due to explicit inversions with deep lakes of cold air, it is smaller. It is also necessary to be aware of the fact that the thermal belt is a dynamic phenomenon, subject to great changes also in relation to individual weather conditions, which has also been corroborated by the measurements. 